\title{
Nutritional Potential and Bioactive Compounds in Cereus jamacaru DC: An Multifaceted Cactus From Brazilian Semiarid
}

\author{
Michelle Maylla Viana de Almeida \\ Universidade Federal Rural de Pernambuco, Brazil
}

Fernando dos Santos Araújo, Alberício Pereira Andrade, Pedro Gregório Vieira Aquino, Roberta de Lima Valença

Universidade Federal do Agreste de Pernambuco, Brazil

Riselane de Lucêna Alcantara Bruno

Universidade Federal da Paraíba, Brazil

Received: September 16, 2021 Accepted: January 3, 2022 Published: January 10, 2022

doi:10.5296/jas.v10i1.19006

URL: https://doi.org/10.5296/jas.v10i1.19006

\begin{abstract}
Cereus jamacaru DC. is an endemic cactus of the Brazilian semiarid region empirically used by humans for forage, food and medicinal purposes. In this paper, we characterize the physicochemical and phytochemical profile of the $C$. jamacaru cladode and fruits, outlining their nutritional implications. We evaluate the basic physicochemical characteristic of the fruits and the main classes of chemical compounds present in aqueous and ethanolic extracts from cladode, peel, and pulp of ripe and semi-ripe fruits through qualitatively and quantitatively methods. We analyze the data through descriptive statistics and variance analysis. The fruits have appropriate $\mathrm{pH}$, acidity, and total soluble solid levels for the fruit processing industry and fresh consumption. We identified the presence of saponins, tannins, flavones, flavonols, and xanthones in all samples, but alkaloids and steroids were both detected in cladodes exclusively. The phenolic compound and flavonoid contents vary according to the extraction method and sample class. The cladodes and pulp of ripe fruits have the highest flavonoid levels, while the content of phenolic compounds had a high level in peels of ripe and semi-ripe fruits. The presence of these bioactive compounds implies that
\end{abstract}


C. jamacaru products have relevant pharmacological interest and functionality for human (fruits) and domestic ruminant (cladodes) food. These applications can boost the agricultural-economic exploration of $C$. jamacaru and contribute to income generation, and improve human and animal nutrition.

Keywords: cactaceae, fruit, cladode, caatinga, secondary metabolites, semiarid region

\section{Introduction}

The Brazilian Seasonally Dry Tropical Forest, the so-called "Caatinga", covers an area of $912,529 \mathrm{~km}^{2}$ in the semi-arid region of Northeastern Brazil (Silva, Leal and Tabarelli, 2017). The Caatinga supplies multiple environmental services and has potential for sustainable extractive activities of timber and non-timber forest products, including edible fruits and bioactive substances. However, a wide range of useful plants is still poorly explored, probably because their products were not characterized enough to drawn attention to the food and pharmaceutical sectors.

Cactaceae is a plant family abundant in the Caatinga (Sampaio and Costa, 2011) that contains several useful species for humans. Cereus jamacaru DC., popularly known as mandacaru, is one of this useful Cactaceae specie for humans (Sales et al., 2014) because its fruits are edible and the stem (cladode) is a source of domestic ruminant food.

The $C$. jamacaru cladodes are multi-articulate with candelabriform branches. Besides being an important food source for cattle during the dry season (Zara et al., 2012), the cladodes also have antimicrobial, vasodilatory (Messias, 2010), anti-inflammatory, and contraceptive actions (Andrade et al., 2006), as experimentally demonstrated in rodents. The $C$. jamacaru fruit is an oblong ellipsoid-shaped berry, its pulp is white funicular and mucilaginous with black-colored seeds (Rocha and Agra, 2002) frequently consumed in natura or as juices and jellies by the locals.

Although the $C$. jamacaru phytochemical profile has been investigated before by several authors, including Bevilaqua et al. (2015), Santos et al. (2019), Dutra et al. (2019), and Medeiros et al. (2018), there are still other aspects to be studied, such as the phytochemical characterization of different parts of the plant using different extraction methods, as this would extend knowledge about its pharmacological and nutritional properties.

In order to emphasize the importance of this species as a powerful source of bioactive compounds and highlight its chemical composition versatility and the possibility of many uses, we evaluated the basic physicochemical characteristic of the fruits and the main classes of chemical compounds present in aqueous and ethanolic extracts of the $C$. jamacaru cladodes and fruits.

\section{Method}

\subsection{Collection and Preparation of the Samples}

We collected the fruit and cladode samples (Figure $1 \mathrm{D})$ in ten individuals $(\mathrm{n}=10)$ from a $C$. jamacaru natural population located on private property ( $\left.09^{\circ} 01^{\prime} 49^{\prime \prime} \mathrm{S}, 36^{\circ} 24^{\prime} 07^{\prime \prime} \mathrm{W}\right)$ in the municipality of Brejão, Pernambuco state, Brazil. The site climatic classification based on Köppen-Geiger is Cs'a-type (mesothermal including hot and dry summer). The predominant vegetation is Subcaducifolic and Deciduous Tropical Forest-types (Santos et al., 2018).

After collection, we transported the samples under refrigeration to the processing site. 


\section{Ml Macrothink}

According to their color, we grouped the fruits in two maturation stages: ripe (predominantly red peel) and semi-ripe (reddish-green peel) (Fig. 1 A and B).

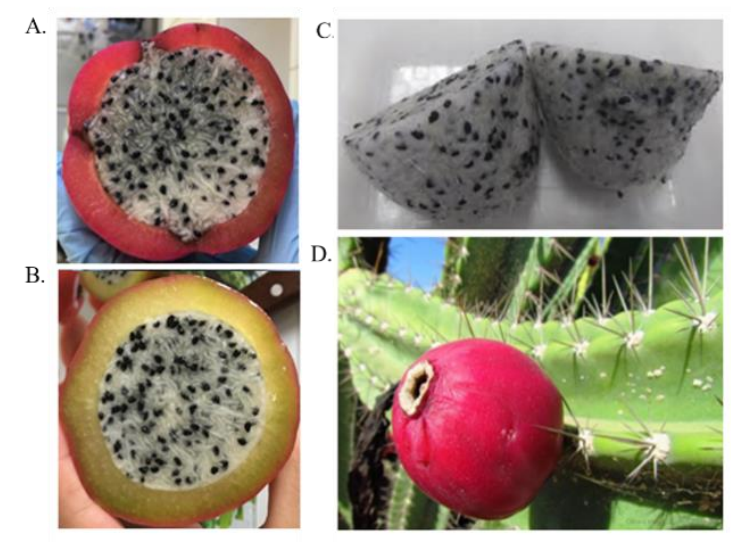

Figure 1. Ripe fruit (A), semi-ripe fruit (B), fruit pulp (C), fruit and cladode (D) of $C$. jamacaru

After fruits washed and sanitized with sodium hypochlorite (100 ppm), we manually separated the fractions of peel (epicarp + mesocarp) and pulp (endocarp + seeds) (Fig. 1A and C), resulting in four classes of samples afterward: ripe peel (RP), semi-ripe peel (SP), ripe pulp (RP), and semi-ripe pulp (SP). These samples were frozen $\left(-10^{\circ} \mathrm{C}\right)$, lyophilized (Terroni Lyophilizer, model Series LS 3000), grounded, packed in hermetically-sealed glass pots, and, finally, stored at $25^{\circ} \mathrm{C}$.

We properly cleaned the cladodes and removed their thorns manually. Then, they were horizontally sliced into $2.0 \mathrm{~cm}$ thick pieces and dried in a forced air circulation system $\left(50{ }^{\circ} \mathrm{C}\right.$ for 72 hours). The dry material was ground in a Cutting Mill (Willey®), packed in hermetically-sealed glass pots, and stored at $25^{\circ} \mathrm{C}$.

\subsection{Basic Physicochemical Characterization of the Fruits}

For the physicochemical characterization, we determined: a) $\mathrm{pH}$ - using the potentiometric method; b) total soluble solids - using the refractometry on Brix scale ( ${ }^{\circ}$ Brix); c) titratable acidity - using the volumetric titration method (\% citric acid/100g of the sample). Such methodologies are available in AOC (1992).

\subsection{Phyto Chemical Prospection}

\subsubsection{Obtaining Extracts}

The vegetal extracts were obtained through aqueous and ethanolic extractions. In aqueous extraction, we mixed $100 \mathrm{~g}$ of the sample with $1.0 \mathrm{~L}$ of distilled water. Then, we constantly heated and shaken the mixture up to $90{ }^{\circ} \mathrm{C}$, which remained at this temperature for $5 \mathrm{~min}$. Right after, we placed the extract in hermetically-sealed glass pots and stored it at $-10{ }^{\circ} \mathrm{C}$.

In ethanolic extraction, we mixed $100 \mathrm{~g}$ of the sample with $1.0 \mathrm{~L}$ of ethanol $(95 \%)$ - extracting solvent. The extraction was exhaustive, i.e., we put this sample and the extracting solvent together at $25^{\circ} \mathrm{C}$ for eight days. We shook the mixture day after day, whereas we renewed the extracting solvent every two days. By using a rotary evaporator at $40{ }^{\circ} \mathrm{C}$, we filtered and concentrated the mixture afterward (Vizcaino, 2007). The extract was stored in hermetically-sealed glass pots at $-10^{\circ} \mathrm{C}$. 


\subsubsection{Identification of the Main Classes of Chemical Compounds}

We identified the main classes of chemical compounds according to the methods proposed by Matos (2009) and Desoti et al. (2009). We used $1 \mathrm{mg} / \mathrm{mL}$ of extract (aqueous and ethanolic) for qualitative chemical tests. The steroids were detected by the Liebermann-Burchard reaction, while tannins by precipitation methods with iron salts, flavonoids through Shinoda and Taubouk reactions, as saponins by analysis of persistent foaming after extract agitation. In contrast, we performed chemical tests with specific reagents to check for the presence of phenols, flavones, flavonols, xanthones, catechins, anthocyanins, anthocyanidins, terpenoids, and flavanones, as described in table 1. The interpretation made was based on the characteristic visual patterns.

Table 1. Phytochemical prospecting of crude ethanolic and aqueous extracts from Cereus jamacaru DC

\begin{tabular}{lll}
\hline Secondary metabolites & Characterization reactions & $\begin{array}{l}\text { Changes observed in } \\
\text { positive results }\end{array}$
\end{tabular}

Steroids

Terpenoids

Saponins

Alkaloids

Phenols

Tannins

Condensable / hydrolyzable

CCD

Reagent Dragendorff

$\mathrm{FeCl}^{3}$

Precipitation with iron salts

Blue or green precipitate

Flavones/flavonois

/xanthones

Acidulation / alkalinization

Color change

Detection of the alkaloids chemical group was performed by thin-layer chromatography (CCD) using specific eluent and developer systems according to Cechinel Filho and Yunes (1998).

2.3.3 Content of Total Phenolic Compounds (CFT) and Total Flavonoids (FT)

We estimated CFT content through the modified Folin-Ciocalteau method by Roesler et al. (2007). We mixed $100 \mu \mathrm{L}$ of extract $(1: 10 \mathrm{p} / \mathrm{v})$ with $500 \mu \mathrm{L}$ of the Folin-Ciocalteau reagent and $400 \mu \mathrm{L}$ of $\mathrm{Na}_{2} \mathrm{CO}_{3}$ solution $(7.5 \%)$. The samples were shaken and heated $\left(50{ }^{\circ} \mathrm{C}\right)$ for 5 
min, then cooled at $25^{\circ} \mathrm{C}$. The absorbance of the liquid fraction was measured at $760 \mathrm{~nm}$ using a UV-vis spectrophotometer (model 700 Femto® plus). A calibration curve of gallic

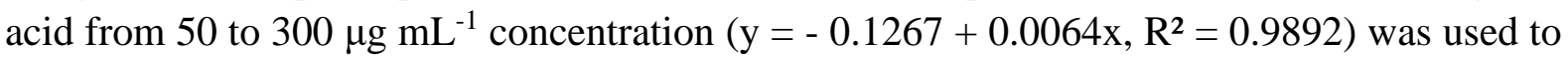
estimate the CFT content in the samples. We performed determinations in triplicate, and the results were expressed in milligrams of gallic acid equivalents in $100 \mathrm{~g}$ of dry matter $(\mathrm{mg}$ EAG/100g MS).

We estimated FT content according to the method described by Woisky and Salatino (1998). We mixed $0.5 \mathrm{ml}$ of extract with $0.5 \mathrm{ml}$ of $\mathrm{AlCl}^{3}$ solution (5\%). We left the mixture resting for 30 minutes at $25^{\circ} \mathrm{C}$ with no light. The liquid fraction absorbance was measured at $425 \mathrm{~nm}$ using a UV-vis spectrophotometer (model 700 Femto ${ }^{\circledR}$ plus). A quercetin calibration curve from 50 to $300 \mu \mathrm{g} \mathrm{mL}^{-1}$ concentration $\left(\mathrm{y}=0.0011 \mathrm{x}+0.0078, \mathrm{R}^{2}=0.9885\right)$ was used to estimate the FT content in the samples. We carried out determinations in triplicate, and the results were expressed in milligrams of quercetin equivalents in $100 \mathrm{~g}$ of dry matter $(\mathrm{mg}$ $\mathrm{EQ} / 100 \mathrm{~g} \mathrm{MS})$.

\subsection{Data Analysis}

We used the descriptive statistics (median, standard deviation, minimum, first quartile, second quartile, third quartile, and maximum) in boxplot for data analysis concerning to basic physicochemical characterization of the fruits. As these data also attended to the parametric analysis assumptions, we used the Variance Analysis (ANOVA) to compare the treatments through the statistical software BioEstat 5.0.

The data concerning both contents of total phenolic compounds and total flavonoids also attended to the parametric analysis assumptions and hence were analyzed through ANOVA in a double factorial scheme $(5 \times 2)$. Factor 1 concerns the sample class (cladode, ripe and semi-ripe peel, ripe and semi-ripe pulp), and the second factor concerns the extract type (aqueous and ethanolic). We compared the averages through the Tukey test at 5\% probability level. We performed the analyses using the SISVAR 5.6 statistical program.

\section{Results}

\subsection{Basic Physicochemical Characterization of the Fruits}

We noticed a higher acidity level $(\mathrm{P}=0.0032)$ in the peel of semi-ripe fruits (Figure 2A). However, the acidity (Fig. $2 \mathrm{~B})$ and $\mathrm{pH}(\mathrm{P}=0.01)$ levels in the pulp were similar between the two ripening stages (Fig. $2 \mathrm{C}$ and $2 \mathrm{D}$ ). The content of soluble solids was higher $(\mathrm{P}<0.01)$ in the peel and pulp of ripe fruits (Fig. 2 - E and F). 

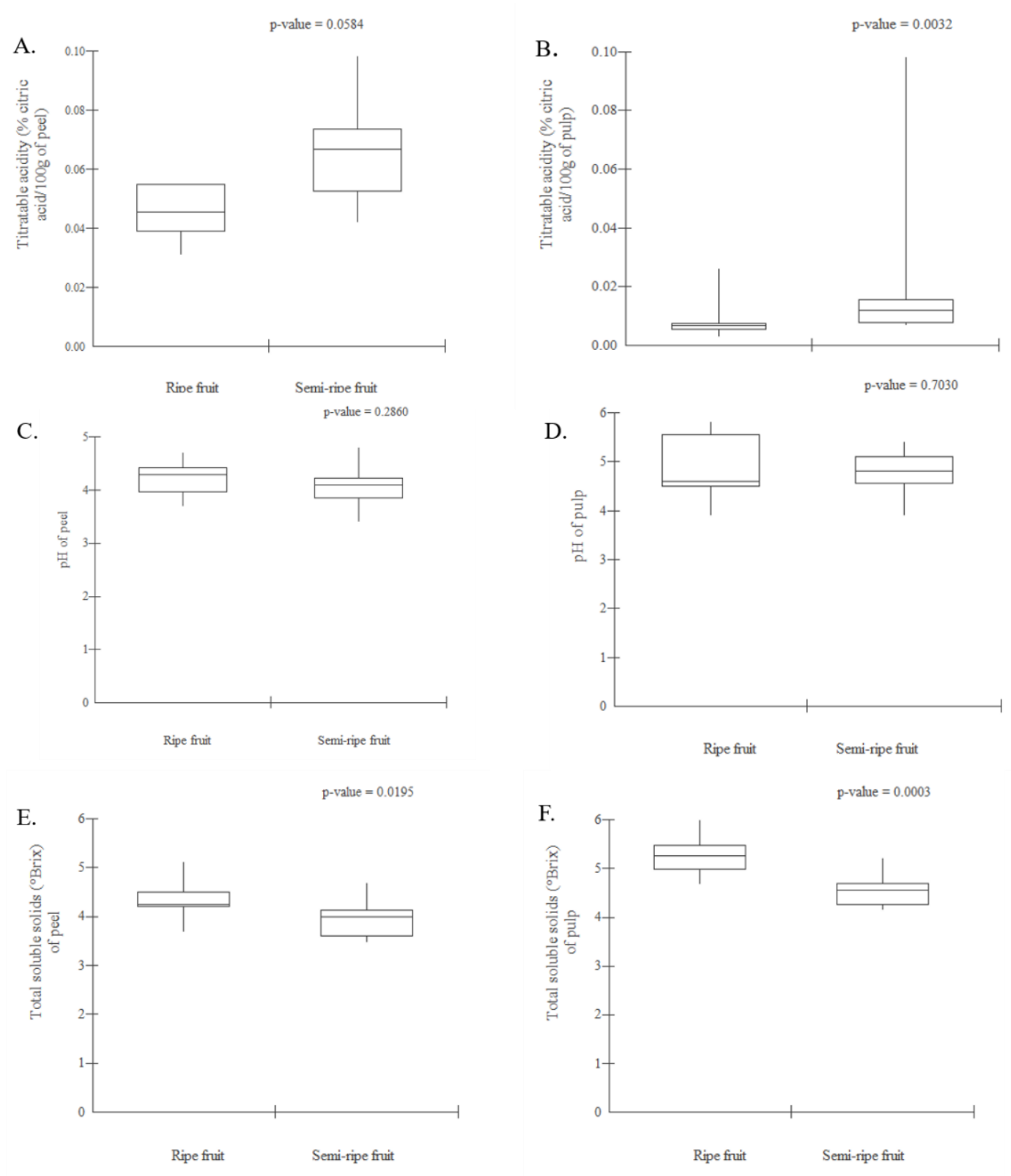

Figure 2. Physicochemical attributes of $C$. jamacaru ripe and semi-ripe fruits. A - the peel titratable acidity; $\mathrm{B}$ - the pulp titratable acidity; $\mathrm{C}$ - the peel $\mathrm{pH} ; \mathrm{D}$ - the pulp $\mathrm{pH}$; $\mathrm{E}$ - the peel soluble solids content; $\mathrm{F}$ - the pulp soluble solids content

\subsection{Phyto Chemical Prospection}

We found in all samples the presence of phenols, flavones, flavonols, xanthones, and saponins (Table 2). The presence of steroids and alkaloids occurred in cladodes ethanolic extraction only. Moreover, we found Alkaloids in both ethanolic extractions of cladodes and ripe-fruit peels. Terpenoids, in turn, were found in peel and pulp of ripe and semi-ripe fruits only. We found no presence of anthraquinones, anthrones, coumarins and tannins (condensed and hydrolyzable). 
Table 2. Qualitative phytochemical profile of the $C$. jamacaru cladode and fruit fractions in function of extraction methods

\begin{tabular}{|c|c|c|c|c|c|c|c|}
\hline $\begin{array}{l}\text { Sample } \\
\text { class }\end{array}$ & & Alkaloids & Steroids & Terpenoids & Saponins & Phenols & Flavones/Flavonoids/Xanthomas \\
\hline Cladode & \multirow{7}{*}{ 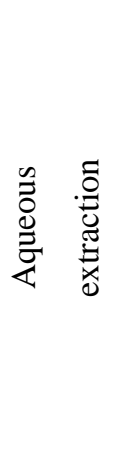 } & - & - & - & + & + & + \\
\hline Ripe peel & & - & - & + & + & + & + \\
\hline Semi-ripe & & & & & & & \\
\hline peel & & - & - & + & + & + & + \\
\hline Ripe pulp & & - & - & + & + & + & + \\
\hline Semi-ripe & & & & & & & \\
\hline pulp & & - & - & + & + & + & + \\
\hline Cladode & \multirow{7}{*}{ 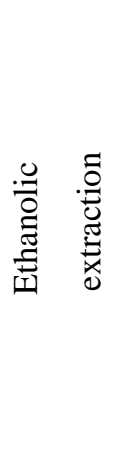 } & + & + & - & + & + & ++ \\
\hline Ripe peel & & - & - & + & ++ & + & ++ \\
\hline Semi-ripe & & & & & & & \\
\hline peel & & - & - & + & + & + & + \\
\hline Ripe pulp & & - & - & + & + & + & ++ \\
\hline Semi-ripe & & & & & & & \\
\hline pulp & & - & - & + & + & + & + \\
\hline
\end{tabular}

Reaction intensity: “+++" (high); "++" (mean); “+” (low), and “-” (negative reaction).

\subsection{Content of Total Phenolic Compounds (CTP) and Total Flavonoids (TF)}

There was an interaction $(\mathrm{P}<0.05)$ among the extraction methods and sample classes for the CTP and TF contents. The CTP contents in cladode and peel of ripe and semi-ripe fruit were higher through ethanolic extraction. However, the pulp of ripe and semi-ripe fruit samples showed the highest CTP contents through aqueous extraction (Fig. 3). The CTP contents in the peel of ripe and semi-ripe fruits were higher than in other samples.

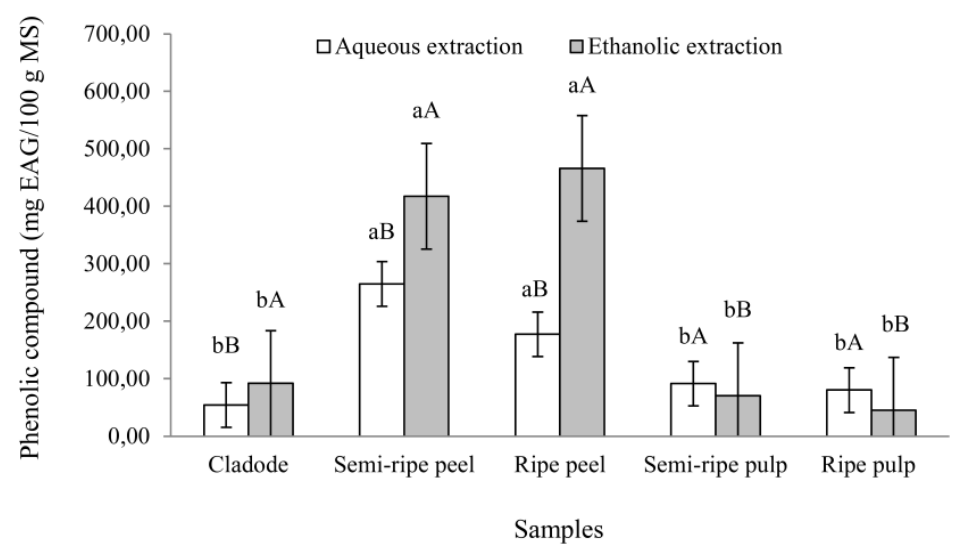

Figure 3. Phenolic compound contents of the C. jamacaru cladode and fruit fractions in function of extraction methods. Averages followed by the same letter do not differ from each other through the Tukey test at 5\% probability. Vertical bars represent the average standard 
error. Uppercase letters compare the extraction method, whereas lowercase ones compare the samples

Thus, the ethanolic extraction proved to be more efficient, as it provided a higher CTP yield (45.36 to $466.33 \mathrm{mg}$ EAG/100 g MS) compared to aqueous extraction (54.48 to $265.10 \mathrm{mg}$ $\mathrm{EAG} / 100 \mathrm{~g} \mathrm{MS})$.

The cladode and pulp of ripe fruits had higher TF contents through aqueous extraction, but peel of ripe and semi-ripe fruits had higher TF contents through ethanolic extraction (Fig. 4). The cladode and pulp of ripe fruits had the highest levels of TF (Fig. 4).

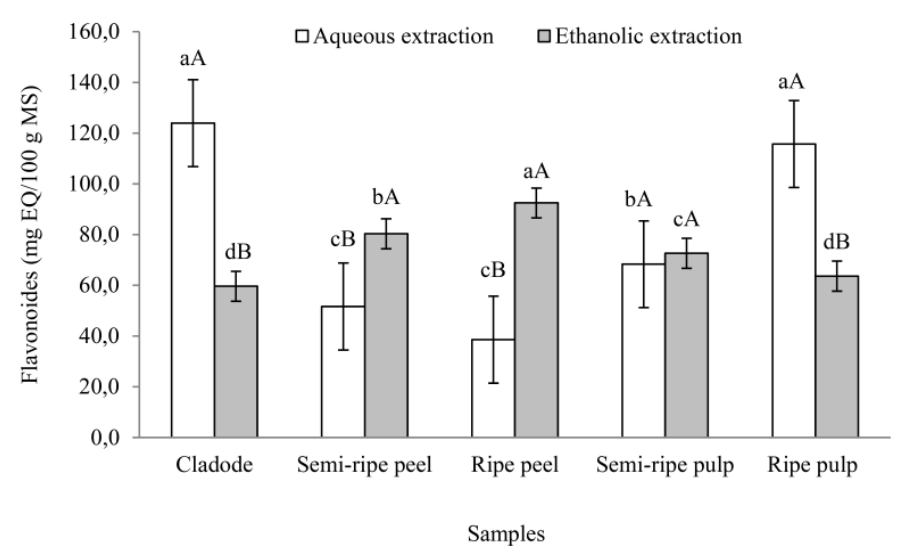

Figure 4. Total flavonoid contents through aqueous and ethanolic extractions in the $C$. jamacaru cladode and fruit fractions. Averages followed by the same letter do not differ from each other through the Tukey test at 5\% probability. Vertical bars represent the average standard error. Uppercase letters compare the extraction method, whereas lowercase ones compare the samples

\section{Discussion}

In this study, we investigated the physicochemical characteristics and phytochemical composition in the $C$. jamacaru cladode and fruit fractions analyzing their pharmacological and nutritional implications accordingly.

\subsection{Physicochemical Attributes of the Fruit Fractions}

The $\mathrm{pH}$ (4.05 to 5.30$)$ and titratable acidity ( 0.0087 to $0.1089 \%$ citric acid) ranges of $C$. jamacaru pulp indicate that this fraction has weak vulnerability to micro-organisms action, which could prolong its longevity after processing. While its total soluble solids content (SST) might be regarded as low (4.0 to $5.67^{\circ} \mathrm{BRIX}$ ), it resembles other native fruits from Brazil (4.0 to $4.5^{\circ} \mathrm{BRIX)}$, such as Psidium cattleyanum S., Mauritia flexuosa Mart. and Byrsonima crassifolia L. Rich), being in concordance with the standard minimum criteria determined by the Brazilian legislation (BRASIL, 2016). Such characterization is relevant for the fruit processing industry because the greater the amount of SST, the greater the juice and pulp yield. In contrast, SST contents of $C$. jamacaru fruits (4.0 to $\left.5.67^{\circ} \mathrm{BRIX}\right)$ were lower than those verified by Almeida et al. (2009) (10.50 and $11.5^{\circ}$ BRIX), which might have happened due to the differences in the ripening stage, plant genotype, and local edaphoclimatic conditions.

There has also been a pulp SST content increasing according to the fruit maturation stage, 
from $3.64{ }^{\circ} \mathrm{BRIX}$ in the semi-ripe stage to $5.21^{\circ} \mathrm{BRIX}$ in the ripe one. Such increase was followed by an acidity decrease, from $0.0982 \%$ in the semi-ripe stage to $0.0570 \%$ in the ripe one. According to Damodaran et al. (2010), such change is due to the converting from citric and malic acids to sugars during the fruit ripening stage.

\subsection{Qualitative Identification of the Main Compound Classes}

We found several secondary metabolites in C. jamacaru, including alkaloids, terpenoids, phenols, and saponins. These compounds were also identified in the studies performed by Cartaxo et al. (2010), Schwarz et al. (2010), Bevilaqua et al. (2015), Santos et al. (2019), Dutra et al. (2019) and Medeiros et al. (2018).

The presence of these bioactive compounds suggests, therefore, $C$. jamacaru fruits have the functional potential for human food. In addition, the presence of terpenoids, saponins, phenols, flavones, flavonols, and xanthones in $C$. jamacaru cladodes also indicates that the product has the functional potential for domestic ruminants' food. A previous study performed by Davet (2005) has identified alkaloids and steroids as the main compounds contained in $C$. jamacaru cladodes, corroborating with the finding ones of this study and scientific literature for Cactaceae. More recently, Medeiros et al. (2018) have identified almost 24 phytochemicals in $C$. jamacaru, including tannins that have not been identified in our study.

\subsection{CTP and FT Yield According to the Extraction Method and Class of Samples}

We found that CTP and TF levels have varied according to the extraction method and class of samples. It probably happened because the extraction methods affect quantity, quality, and bioavailability of the metabolites (Miglio et al., 2008). The extracting solvent influences the release/expression of flavonoid groups (Koubaa et al., 2015) and phenolic compounds (Harbone, 1998), as they vary in polarity, acidity, hydrogen-bonding capacity of hydroxyl groups in the aromatic ring.

While most phenolic compounds can be soluble in water, some compounds present solubility only in organic solvents. In fact, ethanolic solvents may be more efficient in the extraction of total phenolic compounds than water (Vizzoto and Pereira, 2011; Tomsone et al., 2012; Menezes Filho and Castro, 2019). However, the processing degree, the size of particles, the extraction duration, the temperature, and the extracting solvent concentration can all also influence the phenolic compound yields (Shahidi and Wanasundara, 1998).

\subsection{Quantitative Analysis of the Total Phenolic Compounds and Total Flavonoids}

CTP contents in $C$. jamacaru pulp (45.36 - $91.66 \mathrm{mg}$ EAG/100g DM) were higher than those observed by Moreira et al. (2018) (28.35 mg EAG/100g MS), while CTP contents in peels (177.55 - $466.33 \mathrm{mg}$ EAG/100g MS) were also higher than those observed in fruit peels of Pilosocereus pachycladus (173, 8 - 221.9 mg EAG/100 g MS) (Rodrigues et al. (2019), another endemic Cactaceae from Caatinga.

We also found that CTP contents in pulp of C. jamacaru fruits (45.36 - 91.66 EAG/100g DM) were higher compared to the fruits of cactus pear (Opuncia ficus-indica) $(2.51-54.33 \mathrm{mg}$ EAG/100g) (Mabrouki et al., 2015) and lower compared to Pitaya (Hylocereus spp.) (165.24 mg EAG/100g) (Vizzotto et al., 2014), both Cactaceae are cultivated for edible fruit production in Brazil. 
We also believe the higher CTP content in peels (177.55 - $466.33 \mathrm{mg}$ EAG/100g DM) regarding the $C$. jamacaru pulp (45.36 - $91.66 \mathrm{mg} \mathrm{EAG} / 100 \mathrm{~g} \mathrm{DM})$ is probably due to an accumulation of these metabolites in the fruit epidermis because, according to Daiuto et al. (2014), such metabolites act as protection against ultraviolet radiation.

Regarding the FT content in C. jamacaru cladode, the values obtained here (59.65 - 123.94 EQ /100g DM) are similar to those described by Dutra et al. (2019) who used the hydroalcoholic extraction method. In contrast, TF contents in fruit peels $(38.56-92.5 \mathrm{mg}$ $\mathrm{EQ} / 100 \mathrm{~g} \mathrm{DM}$ ) are higher than the ones observed by Araújo et al. (2008) (11.30 - 14.34 $\mathrm{mg} / 500 \mathrm{~g}$ ), indicating existence of intraspecific variability in the content of this secondary compound. This variability in Opuntia spp. is attributed to local abiotic factors such as drought and soil fertility (Figueroa - Cares et al., 2010), as they are capable of inducing changes in the composition of secondary compounds, including flavonoids (Pretti et al., 2018). These polyphenols have antioxidant, anti-cancer (Dutra et al., 2018), anti-inflammatory (Araújo et al., 2008; Ferreira Júnior et al., 2011), and antibacterial (Davet et al., 2009) actions that are relevant to pharmacology.

\section{Conclusions}

The phenolic compound and flavonoid contents vary according to the extraction method and sample class. The cladodes and pulp of ripe fruits have the highest flavonoid contents, while the peels of ripe and semi-ripe fruits have higher phenolic compound contents. The presence of these bioactive compounds indicates that $C$. jamacaru products have great potential for human (fruits) and domestic ruminants (cladodes) foods and pharmacological use. These applications can boost the agricultural-economic exploration of $C$. jamacaru and contribute to income generation, and improve human and animal nutrition.

\section{References}

Almeida, M. M., Silva, F. L. H., Conrado, L. S., Freire, R. M. M., \& Valença, A. R. (2009). Caracterização física e físico-química de frutos do mandacaru. Revista Brasileira de Produtos Agroindustriais, 11(1), 15-20.

Andrade, C. T. S., Marques, J. G. W., \& Zappi, D. C. (2000). Utilização medicinal de cactáceas por sertanejos baianos. Revista Brasileira de Plantas medicinais. Campinas, 8(3), $36-42$.

Araújo, T. A. de S., Alencar, N. L., Amorim, E. L. C. de., \& Albuquerque, U. P. de. (2008). A new approach to study medicinal plants with tannins and flavonoids contents from the local knowledge. Journal Ethnopharmacol, 120, 72-80. https://doi.org/10.1016/j.jep.2008.07.032

Associação do Semiárido Brasileiro - Asa Brasil. (2017). Semiárido - é no semiárido que a vida pulsa. Recuperado em 16 de maio de 2019 em: https://asabrasil.org.br/semiarido\#biomas-semiarido

Association of Official Agricultural Chemistry AOC. (1992). Official methods of analysis of the Association of the Agricultural. (11 ed). AOAC, Whashinghton.

Bevilaqua, M. R. R., Arquimedes, P., Santana Filho, C. A. M., Oliveira, A. J. B., \& Machado, M. F. P. S. (2015). Genetic and chemical diversity in seeds of cactus mandacaru (Cereus sp.) 
from two edaphoclimatic regions contrasting. Anais da Academia Brasileira de Ciências, 87(2). https://doi.org/0.1590/0001-3765201520140029

Brasil - Ministério da Agricultura e do Abastecimento. /Secretaria de defesa agropecuária. Portaria no - 58, de 30 de agosto de 2016, definida pelo artigo 19 do Decreto ${ }^{\circ}$ 6.871/2009. Recuperado em 12 de julho de 2019 em: https://www.in.gov.br/materia/-/asset_publisher/Kujrw0TZC2Mb/content/id/21291257

Cartaxo, S. L., Souza, M. M. A., \& Albuquerque, U. P. (2010). Medicinal plants with bioprospecting potential used in semi-arid northeastern. Journal Ethnopharmacologia, 131(2), 326-342. https://doi.org/10.1016/j.jep.2010.07.003

Cechinel Filho, V., \& Yunes, R. A. (1998). Estratégias para obtenção de compostos farmacologicamente ativos a partir de plantas medicinais. Conceitos sobre modificação estrutural para otimização da atividade. Química Nova, 21, 99-105. https://doi.org/10.1590/S0100-40421998000100015

Daiuto, É. R., Tremocoldi, M. A., Alencar, S. M., Vieites, R. L., \& Minarelli, P. H. (2014) Composição química e atividade antioxidante da polpa e resíduos de abacate 'Hass'. Revista Brasileira de Fruticultura, 36(2), 417-424. https://doi:10.1590/0100-2945-102/13

Damodaran, S., Parkin, K. L., \& Fennema, O. R. (2010). Química de Alimentos de Fennema (4 ed.). Porto Alegre: Artmed.

Davet A. Estudo fitoquímico e biológico do cacto - Cereus jamacaru de Candolle, Cactaceae. 2005. [Dissertação], Universidade Federal do Paraná, Curitiba, 2005, 121 p.

Davet, A., Virtuoso, S., Dias, J. F. G, Miguel, D. M., Oliveira, A. B., \& Miguel, O. G. (2009). Atividade antibacteriana de Cereus jamacaru DC, Cactaceae. Revista Brasileira de Farmacognosia, 19(2). https://doi.org/10.1590/S0102-695X2009000400009.

Desoti, V. C., Maldaner, C. L., Carletto, M. S., Heinz, A. A., Coelho, M. S., \& Dewick, P. M. (2009). The mavalonate and methylerythriol phosphate pathways: terpenoids and steroids. IN: Medicinal Natural Products: a biosynthetic approach. 3 ed, Chichester: Jhon Wiley e Sons, 187-306 p.

Dutra, J. V., Ferreira, M. J., Pereira, P. R. C., Oliveira, J. B. H. Gervásio, S. V., Xavier, M. B., ... \& Batitucci, M. C. P. (2018). Cereus jamacaru D.C. Hydroalcoholic Extract Promotes Anti-Cytotoxic and Antitumor Activity. Pharmaceuticals, 11(4), 130-138. https://doi.org/10.3390/ph11040130.

Dutra, J. V., Oliveira, J. B-H de, Santos, V. S., Pereira, P. R. C., Ferreira, M. J., \& Batitucci, M. C. P. (2019). Fruiting increases total content of flavonoids and antiproliferative effects of Cereus jamacaru D.C. cladodes in sarcoma 180 cells in vitro. Journal of Tropical Medicine, 9(2), 66-72. https://doi.org/10.4103/2221-1691.250857

Ferreira Júnior, W. S., Ladioc, A. H., \& Albuquerque, B. U. P. (2011). Resilience and adaptation in the use of medicinal plants with suspected anti-inflammatory activity in the Brazilian Northeast. Journal Ethnopharmacololy, 138, 238-252. 
https://doi.org/10.1016/j.jep.2011.09.018

Figueroa-Cares, I., Martínez-Damián, M. T., Rodríguez-Pérez, E., Colinas-León, M. T., Valle-Guadarrama, S., Ramírez-Ramírez, S., \& Gallegos-Vázquez, C. (2010). Contenido de pigmentos, otros compuestos y capacidad antioxidante en 12 cultivares de tuna (Opuntia spp.) de México. Agrociencia, 44(7), 763-771.

Harbone, J. B. (1998). Phytochemical Methods - A Guide to Modern Techniques of Plant Analysis. 3 ed, Chapman e Hall, (p. 36-89) Londres.

Koubaa, M., Barba, F. J, Mhemdi, H., Grimia, N., Koubaa, W., \& Vorobiev, E. (2015). Gas assisted mechanical expression (GAME) as a promising technology for oil and phenolic compound recovery from tiger nuts. Innovative Food Science \& Emerging Technologies, 32, 172-180. https://doi.org/10.1016/j.ifset.2015.09.019

Mabrouki, L., Zougari, B., Bendhifi, M., \& Borgi, M. A. (2015). Evaluation of antioxidant capacity, phenol and flavonoid contents of Opuntia streptacantha and Opuntia ficus indica fruits pulp. Revue Nature \& Technologie, 13(1), 02-08.

Matos, F. J. A. (2009). Introdução à fitoquímica experimental. 3ed. (150 p.) Fortaleza: EdUFC.

Medeiros, I. U., Medeiros, R. A., Bortolin, R. H., Queiroz, F. M., Silbiger, V. N., Pflugmacher, S., \& Schwarz, A. (2018). Genotoxicity and pharmacokinetic characterization of Cereus jamacaru ethanolic extract in rats. Bioscience Reports, 39. https://doi.org/10.1042/BSR20180672

Menezes Filho, A. V. P., \& Castro, C. F. S. (2019). Avaliação de diferentes solventes na extração de compostos fenólicos totais em extratos farináceos do fruto de Hymenaea stigonocarpa L. Brazilian Journal of Food Technology, 10(2), 158-169. https://doi.org/10.3895/rebrapa.v10n2.9238

Messias, J. B. (2010). Avaliação dos parâmetros hematológicos e bioquímicos de ratas no segundo terço da gestação submetidas à ação de extrato metanólico de Cereus jamacaru D.C., Cactaceae. Revista Brasileira de Farmacognosia, 20, 478-483. https://doi.org/10.1590/S0102-695X2010000400003.

Miglio, C., Chiavaro, E., Visconti, A., Fogliano, V., \& Pellegrini, N. (2008). Effects of different cooking methods on nutritional and physicochemical characteristics of 634 selected vegetables. Journal of Agricultural and Food Chemistry, 56(1), 139-147. https://doi.org/10.1021/jf072304b

Moreira, I. S., Silva, L. M. M., Castro, D. S., Lima, J. P., Sousa, F. C., Almeida, F. A. C., ... \& Silva, C. M. P. (2018). Fruit of mandacaru: kinetics of drying and physical-chemical characterization, The Journal of Agricultural Science, 10(11), 461. https://doi.org/10.5539/jas.v10n11p461.

Pretti, I. R., Luz, A. C. D., Jamal, C. M., \& Batitucci, M. do C. P. (2018). Variation of biochemical and antioxidant activity with respect to the phenological stage of Tithonia 
diversifolia Hemsl. (Asteraceae) populations. Industrial Crops and Products, 121(1), 241-249. https://doi.org/10.1016/j.indcrop.2018.04.080.

Rocha, E. A., \& Agra, M. F. (2002). Flora do pico do Jabre, Brasil: Cacteceae juss. Acta Botanic. São Paulo, 16(1), 15-21. https://doi.org/10.1590/S0102-33062002000100004.

Rodrigues, T. L., Sousa, A. S. B., Silva, M. C. A, Nascimento, R. S., Sousa, F. R. A., \& Silva, S. M. (2019). Quality, antioxidant and enzymatic activities of facheiro (Pilosocereus pachycladus Ritter) fruits during maturation. Revista Caatinga, 32(4), 1092-1103. https://doi.org/10.1590/1983-21252019v32n426rc

Roesler, R. (2007). Atividade antioxidante de frutas do cerrado. Revista Ciência e Tecnologia de Alimento, 27(1), 53-60. https://doi.org/10.1590/S0101-20612007000100010

Sales, M. de S. L., Martins, L. V., Souza, I., Deus, M. S. M. de, \& Peron, A. P. (2014). Cereus jamacaru de Candolle (Cactaceae): O mandacaru do Nordeste brasileiro. Biologia e Saúde, 20(2), 135-142. https://doi.org/10.5212/Publ.Biologicas.v.20i2.0000

Sampaio, E. V. S. B., \& Costa, T. N. (2011). Estoques e fluxos de carbono no semiárido nordestino: estimativas preliminares. Revista Brasileira de Geografia. 1275-1291.

Santos, H. G dos., Jacomine, P. K. T., Anjos, L. H. C dos, Oliveira, V. A. O., Lumbreras, J. F., Coelho., M. R., Almeida, J. A. de, Araújo Filho, J. C. de, \& Oliveira, J. B. de, \& Cunha, T. J. F. (2018). Sistema Brasileiro de Classificação de Solos. 5. ed, (356 p.) Brasília, Embrapa.

Santos, J. F., Gonçalves, J. L. C., Barros, V. M., Vasvary, E. H. S. C., Garcez Júnior, S. S., \& Moreira, J. J. S. (2019). Estudo prospectivo do cacto Cereus jamacaru DC prospective study of Cereus jamacaru DC cactus. Revista INGI, 3(4), 564-574.

Schwarz, A., Medeiros, I., Mourão, C., Queiroz, F., \& Pflugmacher, S. (2010). Phytochemical and toxic analysis of an ethanol extract from Cereus jamacaru. Toxicology, 196, 344. https://doi.org/10.1016/j.toxlet.2010.03.1089

Shahidi, F., \& Wanasundara, J. P. D. (1998). Food lipids: chemistry, nutrition and biotechnology; Akoh, C. C; Min, D. B., eds.; Marcel Dekker: New York.

Silva, J. M. C., Leal, I. R. \& Tabarelli, M. (2017). The largest tropical dry forest region in South America. Cahm: Springer International Publishing.

Tomsone, L., Kruma, Z., \& Galoburda, R. (2012). Comparison of different solvents and extration methods for isolation of phenolic compounds from horseradish roots (Armoracia rusticana). International Journal of Biological, Biomolecular, Agricultural, 6(4), 236-241.

Vizcaino, R. L. M., Mendoza, D. M., Alcocer, M. S. P., Hernandez, R., Gonzalez, A. M., \& Contreras, A.M.V. (2007). Evaluacion quimica del extracto total etanolico de las hojas y corteza fresca de Muntingia calabura (Elaeocarpaceae), Science Technica, 33.

Vizzotto, M., Schiavon, M. V., Munhoz, P. C., Coelho, D. S., \& Nachtigal, J. C. (2014). Determinação de compostos fenólicos, carotenoides e atividade antioxidante em genótipos de pitaia (espécies não determinadas). XXIII Congresso Brasileiro de Fruticultura. Cuiabá - MT. 


\section{Macrothink}

Journal of Agricultural Studies

ISSN 2166-0379 2022, Vol. 10, No. 1

Woisky, R. G., \& Salatino, A. (1998). Analysis of propolis: some parameters and procedures for chemical quality control. Journal of Apicultural Research, 37(2), 99-105, https://doi.org/10.1080/00218839.1998.11100961

Zara, R. F., Thomazini, M. H., \& Lenz, G. F. (2012). Estudo da eficiência de polímero natural extraído do cacto mandacaru (Cereus jamacaru) como auxiliar nos processos de coagulação e floculação no tratamento de água. Revista de Estudos Ambientais, 14(2), 75-83.

\section{Copyright Disclaimer}

Copyright for this article is retained by the author(s), with first publication rights granted to the journal.

This is an open-access article distributed under the terms and conditions of the Creative Commons Attribution license (http://creativecommons.org/licenses/by/4.0/). 